"Mircea cel Batran" Naval Academy Scientific Bulletin, Volume XIX - 2016 - Issue 1

Published by "Mircea cel Batran" Naval Academy Press, Constanta, Romania // The journal is indexed in:

PROQUEST / DOAJ / DRJI / JOURNAL INDEX / I2OR / SCIENCE LIBRARY INDEX / Google Scholar / Crossref /

Academic Keys / ROAD Open Access / OAJI / Academic Resources / Scientific Indexing Services / SCIPIO

\title{
NUMERICAL MODELLING OF DC ELECTRICAL DRIVE USED IN NAVAL STEERING GEAR
}

\author{
Paul BURLACU 1 \\ Florentiu DELIU ${ }^{2}$ \\ Vasile DOBREF ${ }^{3}$ \\ Petrica POPOV 4 \\ Mitrut C. CARAIVAN ${ }^{5}$ \\ ${ }^{1}$ Lecturer PhD eng.Naval Academy "Mircea cel Batran", Constanta, paul.burlacu@anmb.ro \\ ${ }^{2}$ Lecturer PhD eng.Naval Academy "Mircea cel Batran", Constanta, florentiu.deliu@anmb.ro \\ ${ }^{3}$ Professor PhD eng. Naval Academy "Mircea cel Batran", Constanta, vasile.dobref@anmb.ro \\ ${ }^{4}$ Lecturer PhD Naval Academy "Mircea cel Batran", Constanta, petrica.popov@anmb.ro \\ ${ }^{5}$ PhD eng. Naval Academy "Mircea cel Batran", Constanta, caraivanmitrut@gmail.com
}

Abstract: The steering gear of a ship is an important system used for controlling speed and angle of a propeller. The purpose of the article is to present the speed regulation of DC motor (increase and decrease speed) used for the ship steering gear system.

Keywords: speed regulation; steering gear system

\section{Introduction}

The naval steering gear system is an important device that have the role to adjust the ship speed and propeller power. The purpose of this article is to present a Simulink DC motor model that could be used in naval steering system. This motor is rarely used because of the high costs regarding network supply.

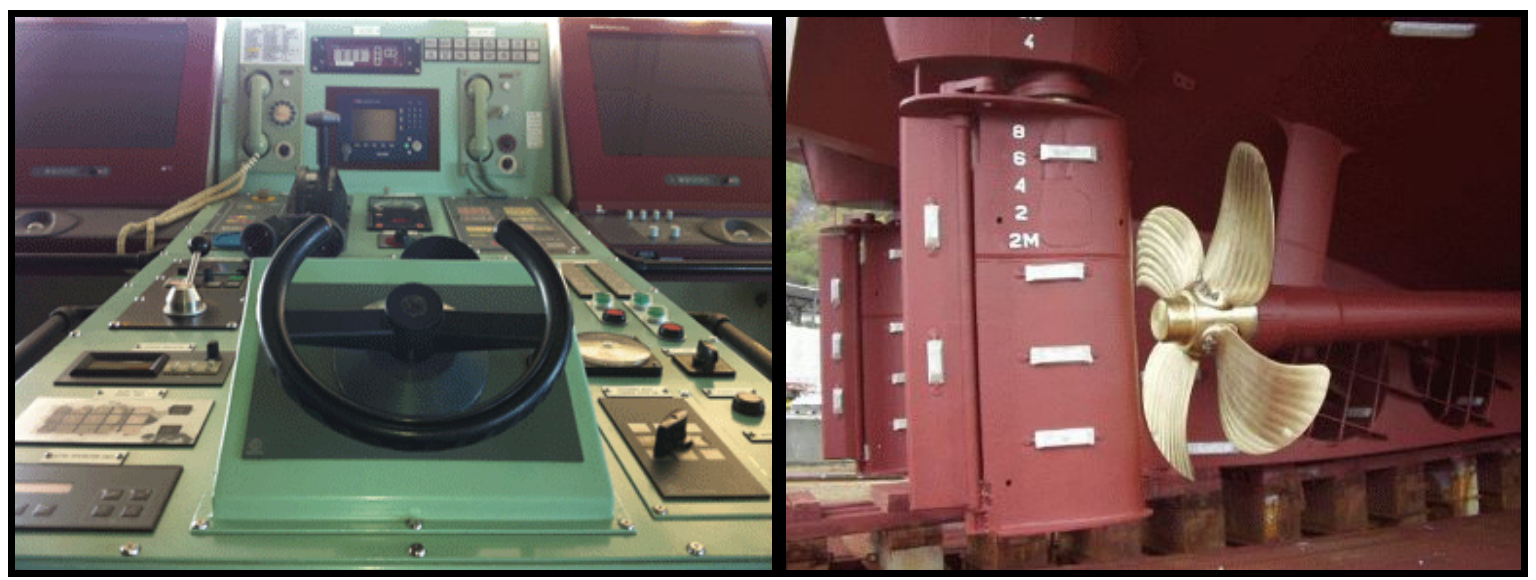

Figure 1

\section{The DC Motor Model}

The DC Motor block represents the electrical and torque characteristics of a DC motor using the following equivalent circuit model:

For the equivalent circuit parameters, the resistor $R$ corresponds to the resistance that is specified in the Armature resistance parameter. The inductor $L$ corresponds to the inductance that is specified in the Armature inductance parameter. The permanent magnets in the motor induce the following back emf $v_{\mathrm{b}}$ in the armature:

$$
v_{b}=k_{v} \omega
$$

Where $k_{v}$ is the back-emf constant and $\omega$ is the angular velocity. The motor produces the following torque, which is proportional to the motor current $i$ :

$$
T_{E}=k_{\mathrm{t}} i
$$

where $k_{\mathrm{t}}$ is the Torque constant. 
"Mircea cel Batran" Naval Academy Scientific Bulletin, Volume XIX - 2016 - Issue 1

Published by "Mircea cel Batran" Naval Academy Press, Constanta, Romania // The journal is indexed in: PROQUEST / DOAJ / DRJI / JOURNAL INDEX / I2OR / SCIENCE LIBRARY INDEX / Google Scholar / Crossref /

Academic Keys / ROAD Open Access / OAJI / Academic Resources / Scientific Indexing Services / SCIPIO

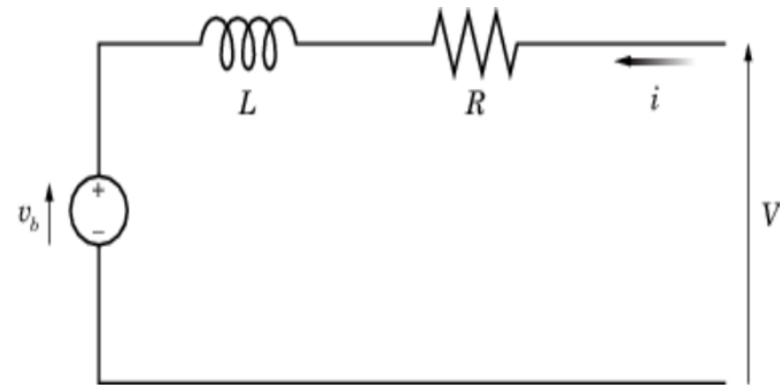

Figure 2

The DC Motor block assumes that there are no electromagnetic losses. This means that mechanical power is equal to the electrical power dissipated by the back emf in the armature. Equating these two terms gives:

$$
\begin{aligned}
& T_{E} \omega=v_{b} i \\
& k_{\mathrm{t}} i \omega=k_{\mathrm{v}} \omega i \\
& \qquad k_{v}=k_{\mathrm{t}}
\end{aligned}
$$

As a result, that could be specified either $k_{\mathrm{v}}$ or $k_{\mathrm{t}}$ in the block dialog box.

The torque-speed characteristic for the DC Motor block is related to the parameters in the preceding figure. When is set up the Model parameterization parameter to By stall torque \& no-load speed or By rated power, rated speed \& no-load speed, the block solves for the equivalent circuit parameters as follows:

1. For the steady-state torque-speed relationship, $L$ has no effect.
2. Sum the voltages around the loop and rearrange for $i$ :

$$
i=\frac{V-W_{b}}{R}=\frac{V-k_{Y} W}{R}
$$

3. Substitute this value of $i$ into the equation for torque:

$$
T_{E}=\frac{k_{E}}{R}\left(V-k_{v} \omega\right)
$$

When is set up the Model parameterization parameter to By stall torque \& no-load speed, the block uses the preceding equation to determine values for $R$ and $k_{\mathrm{t}}$ (and equivalently $k_{\mathrm{v}}$ ).

When is set up the Model parameterization parameter to By rated power, rated speed \& no-load speed, the block uses the rated speed and power to calculate the rated torque. The block uses the rated torque and noload speed values in the preceding equation to determine values for $R$ and $k_{\mathrm{t}}$.

The block models motor inertia $\mathrm{J}$ and damping $\lambda$ for all values of the Model parameterization parameter. The resulting torque across the block is:

$$
T=\frac{k_{t}}{R}\left(V-k_{v} \omega\right)-j \omega \tilde{\omega}-\lambda \omega(8)
$$

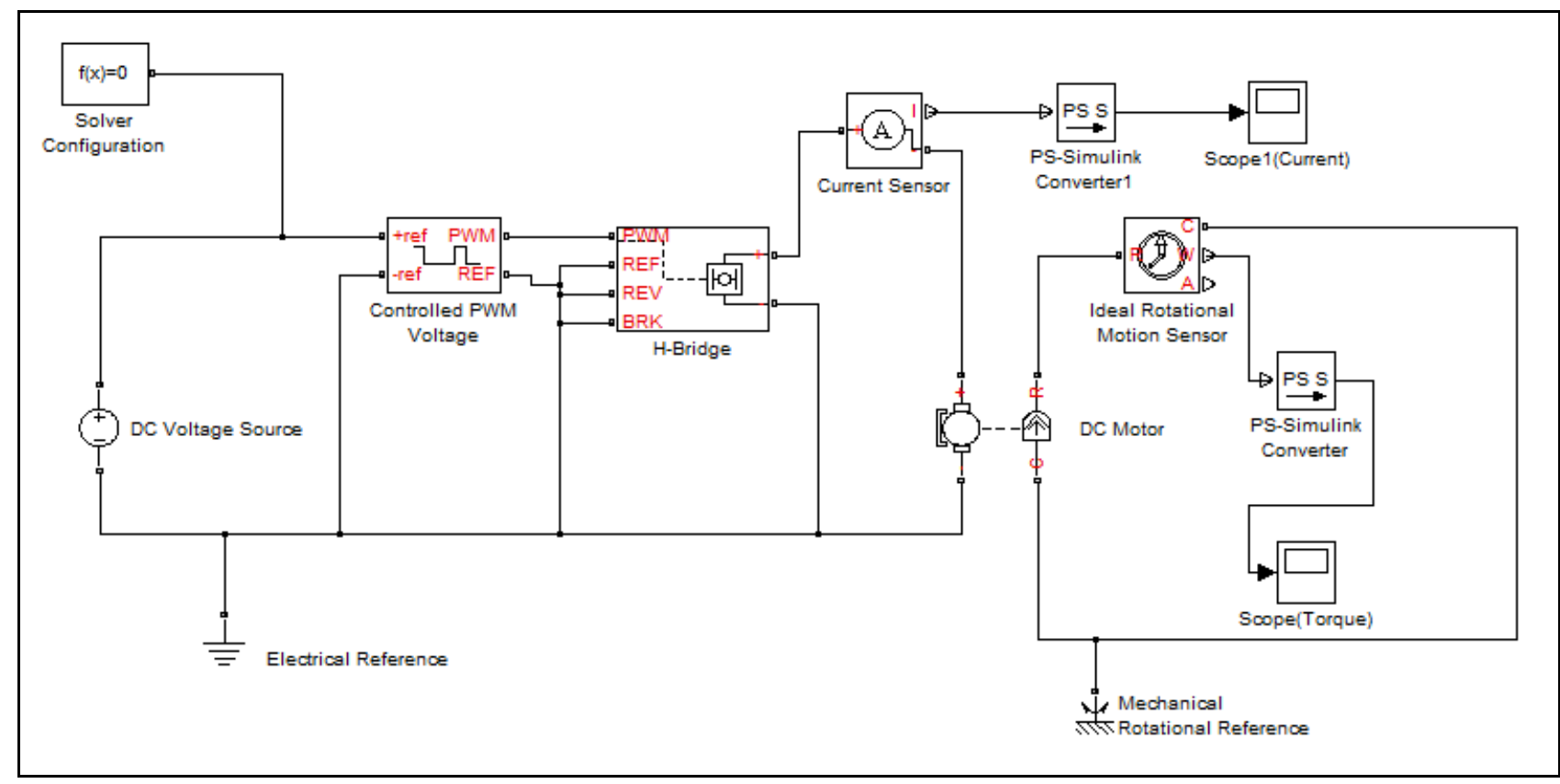

Figure 3

The main parameters are:

- DC Voltage Source: $2.5 \mathrm{~V}$;

- Controlled PWM Voltage: $4000 \mathrm{~Hz}$;

- Armature inductance: $0.01 \mathrm{H}$;
- $\quad$ No-load speed: 4000 rpm;

- $\quad$ Rated speed (at rated load): 2500 rpm;

- Rated load (mechanical power): 10W;

- $\quad$ Rated DC supply voltage: $12 \mathrm{~V}$; 
"Mircea cel Batran" Naval Academy Scientific Bulletin, Volume XIX - 2016 - Issue 1

Published by "Mircea cel Batran" Naval Academy Press, Constanta, Romania // The journal is indexed in:

PROQUEST / DOAJ / DRJI / JOURNAL INDEX / I2OR / SCIENCE LIBRARY INDEX / Google Scholar / Crossref /

Academic Keys / ROAD Open Access / OAJI / Academic Resources / Scientific Indexing Services / SCIPIO

Mechanical parameters:

- $\quad$ Rotor inertia: $2000 \mathrm{~g}^{\star} \mathrm{cm}^{2}$;

- Rotor damping: $10^{-6} \mathrm{~N}^{*} \mathrm{~m} /(\mathrm{rad} / \mathrm{sec})$;

- Initial rotor speed: 0 rpm.

The results that are obtained are presented in next graphs:

The motor current:

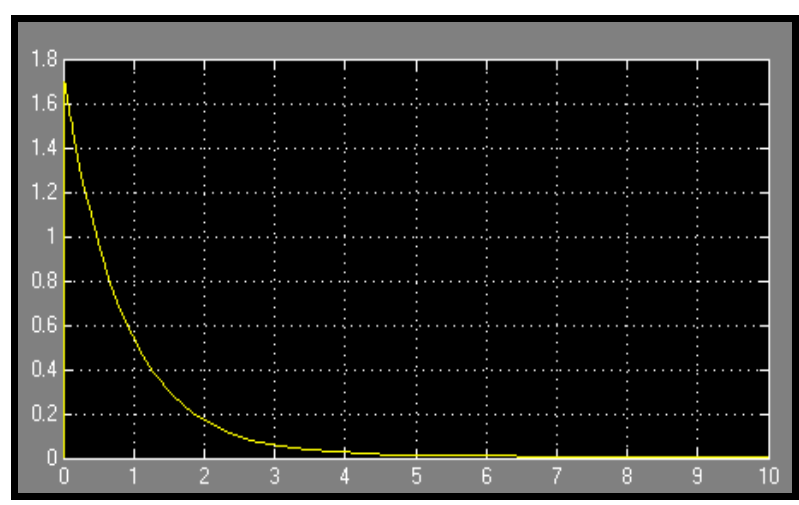

Figure 4
The current from the figure represents the excitation current $(1.7 \mathrm{~A})$ from the $2.5 \mathrm{~V}$ DC source for 10 seconds.

The motor mechanical torque:

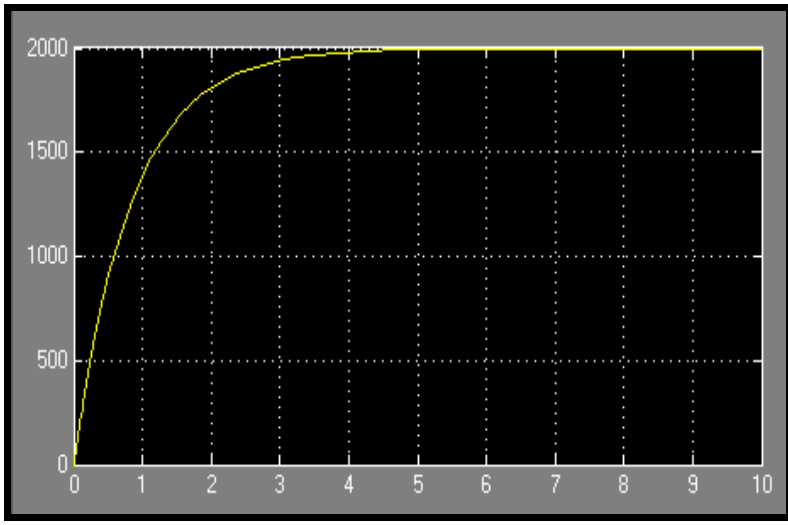

Figure 5

Generally speaking, the DC motor couple is proportional with the current and magnetic field power.

\section{CONCLUSION}

The DC motor could be used as electrical drives because is very easy to change the rotation direction. From the simulation results we can conclude that the DC motor has very short period of time for transitory phenomena so the time response is very short.

\section{BIBLIOGRAPHY}

[1] Bolton, W. Mechatronics: Electronic Control Systems in Mechanical and Electrical Engineering, 3rd edition Pearson Education, 2004.

[2] P.C. Krause. Analysis of electric machinery. McGraw Hill, 1986.

[3] Park. J.K Control of state-constrained linear dynamical systems: Antireset windup approach, IEEE Proc. Control Theory Appl. Vol.147, No.2 February 2000

[4] Babescu M., Păunescu D., Electrical Machines - mathematical analysis of the transitional arrangements,

Ed. Polithenica, Timişoara, 2001 